\section{DR. BRAXTON HICKS' METHOD OF VERSION IN PLACENTA PRAVIA.}

\section{To the Editor of THE LANCET.}

SrR,-To add to the interest of the above-mentioned subject, I forward to you the following account of a case treated according to the plan recommended by Dr. Hicks :-

On the evening of July $28 \mathrm{th}$, I was called by a midwife to see Mrs. F-, who was said to be flooding. She is a stout, healthy person, aged twenty-five, and within three weeks of the full term of her third pregnancy. She has suffered from hæmorrhage twice during the last five weeks. Yesterday it recommenced, and this evening a large quantity of blood has passed with very slight labour pains. I arrived about a quarterpast nine P.M. Blood was slowly passing away. She appeared pale, and the pulse was feeble, but not rapid. I immediately made an examination, and found the placenta presenting, the os uteri being dilated at least two inches. I introduced $\mathrm{my}$ hand into the vagina, when a strong pain came on, forcing the placenta onwards. I grasped it, and tried to assist its downward progress, at the same time a free discharge of blood was taking place. Fearing $I$ should not soon succeed in removing the placenta, and should have some risk from hæmorrhage during its separation, I examined carefully for membranes, and succeeded in detecting high up, posteriorly, a smooth surface, through which I could feel the head of the foetus. I pressed the head upwards, at the same time manipulating with the other hand on the abdomen. I soon felt the outlines of the arms, and, rupturing the membranes, $I$ directly managed to hook down a knee, which I drew well through the os uteri. The hæmorrhage then ceased. I gave freely of brandy-andwater, with a dose of secale, and did not assist further the delivery until about twenty minutes had elapsed, and the pulse had become moderately full. I now used slight traction with the pains, and in a few minutes the child was born. The cord did not pulsate from the first. I think the child had been dead some time. It was small. The placenta passed immediately, and the uterus contracted well without hæmorrhage. The midwife, who had been in attendance since four P.M., calculated she had seen over two quarts of blood passed. I saw in the chamber utensil above a quart. The case is progressing favourably.

The placenta on examination was found lacerated, one edge of the rent corresponding with the insertion of the cord. As the placenta was in this case almost centrally situated over the os uteri, I believe Dr. Hicks' plan will be found generally useful, and that turning may be performed without introducing more than the fingers into the uterus. It is stated by some that hæmorrhage in these cases takes place from the placenta, where it is disconnected from the uterus. In this case I am as certain as I well can be that the blood did not pass from the exposed placenta, but from the inner surface of the uterus. I remain, Sir, yours truly, JOSEPII BATCPOFT, M.D.

St. James'-street, Nottingham, July 30th, 1860.

** In Dr. Lee's "Clinical Midwifery" there are related many cases of turning without introducing the hand into the uterus.-ED. I.

\section{QUININE IN SCARLATINA MALIGNA.}

\section{To the Editor of THE LANCET.}

Sin, - Having read in your journal of July $28 \mathrm{th}$ a brief account of scarlatina maligna proving fatal in about forty-eight hours, I venture to ask the writer of the case in question why he omitted from his long list of remedies the only reliable agent, disulphate of quinine? He mentions diuretics, diaphoretics, narcotics, and saline mixtures. He blistered the temples and nape of the neck, and applied cold to the head. But, without wishing to impugn his treatment, I cannot express any surprise at the result. For those who may have such cases to meet-and no doubt they occur only too of ten-I can forcibly recommend the use of quinine. My attention was first ealled to it, in this disease, by the excellent little work of Mr. Peter Hood, in which he so strongly urges its adoption in all forms of scarlet fever. I have put his plan to an extensive test in a large dispensary practice, and have every reason to bear testimony to its success. Without intruding further on your valuable space,

I am, Sir, your obedient servant,

County Ophthalmic Hospital, Maidstone, July, 1860. J. HAwKES,

\section{SOCIETY FOR THE RELIEF OF WIDOWS AND ORPHANS.}

To the Editor of THE LANCET.

SiR,-The publication of your request to the subscribers to the Royal Medical Benevolent College to elect forthwith Mrs Jenner, the widow of the grandnephew of the celebrated Dr. Jenner, has induced me to consider how it has happened that she is placed in so unfortunate a position as to be indebted to a body of friends for an annuity of $£ 15$ a year, when for sixty. three years previously to the death of her husband a society had been established, known as the "Society for the Relief of Widows and Orphans of Medical Men in London and its Vicinity." The object of this Society is to grant, half-yearly, sums in relief of those whom it assists-viz., the widows and children of its deceased members. I, therefore, urge upon all practitioners in medicine residing in Middlesex, or within seven miles of the Post-office, to consider this fact, that for want of a subscription of two guineas a year, this lady is thrown upon her friends, and cannot be elected at the "College" till after three years' canvassing for it; whereas, had her late husband been a member of the "Society" during at least two years prior to his decease, Mrs. Jenner would have been long since in the receipt of half-yearly relief, which would have done much towards providing for her necessities, and would have been accepted by the College as an income of more than. is required of their candidates.

Let all, then, become members of the Society, and give their votes to Mrs. Jenner for the College, as you asked last week; so shall the two societies prosper, not in antagonism, but as relieving the same distress in different ways. The secretary, Dr. Merriman, 53, Berners-street, will forward proposal papers to any who ask for them.
July, 1860.
I am, Sir, your obedient servant,

\section{PARISIAN MEDICAL INTELLIGENCE。}

(FROM OUR SPECIAL CORRESPONDENT.)

The doctrinal discussion was resumed with considerable spirit on the 24th ult., at the Imperial Academy of Medicine. M. Gibert, one of the medical staff of the Hopital St. Louis, and a thorough-bred vitalist, reopened the debate by observing, that in his opinion the real question, whether life is a cause or an effect, had not been touched by any of the preceding speakers, and that any discussion which had not this main question, and its solution, in view, was utterly thrown away. M. Gibert's own attitude towards his fellow vitalists, including M. Trousseau and his school, was anything but friendly. He had taken umbrage, as it seemed, at a very homely illustration made use of by M. Tronsseau, when quoting the words of $M$. Dollfus; the expression, "pot au-feu," applied as a simile in a grave discourse was, he considered, most inappropriate and undignified. Here M. Troussean eame to the rescue of his maltreated metaphor, and covered the retreat of his "batterie de cuisine," giving a sort of Parthian back-thrust in return for one of M. Gibert's cuts at M. Dollfus as being a "triste autorité," by saying, "Yes, but he, at least, had beaucoup d'esprit." M. Gibert's object had been to prove that his quality of vitalism. was the only genuine article, and that of MM. Bouillaud, Trousseau, and Co., was of very inferior brand. He made, however, one good observation, which was that all the organicians must, perforce, adopt somewhat of the vitalist theory, in order to explain the source of their "disposition to function" in the healthy organ; and, in fact, they must either leave their organ in stationary quiescence, or else admit that the animating motor influence was, at the least, a principle akin to the so-called "vital property."

A few more words followed from M. Trousseau to explain that, though he was a vilalist, he wished it to be understood. that he was no animist in his opinions; the latter doctrine implied that the functions of the body were under the immediate influence of the "anima," or soul. This view he considered absurd, as it involved the attribution of a soul to the cabbage, which possessed organs and life as well as the man.

At this moment, M. Bouillaud (evidently a little susceptible on the subject of animism) interrupted the speaker, and said 